\title{
Investigação molecular de Ehrlichia spp. e Anaplasma platys em felinos domésticos: alterações clínicas, hematológicas e bioquímicas $^{1}$
}

\author{
Elisabete S. Correa ${ }^{2 *}$, Giane R. Paludo ${ }^{3}$, Marcela C. Scalon ${ }^{3}$, Josias A. Machado ${ }^{2}$, \\ Ana Carolina Q. Lima ${ }^{2}$, Anderson Teixeira B. Pinto ${ }^{2}$, José Tarcísio L. Thiebaut ${ }^{2}$ \\ e Antônio P. Albernaz ${ }^{2}$
}

\begin{abstract}
Corrêa E.S., Paludo G.R., Scalon M.C., Machado J.A., Lima A.C.Q., Pinto A.T.B., Thiebaut J.T.L. \& Albernaz A.P. 2011. [Molecular investigation of Ehrlichia spp. and Anaplasma platys in domestic cats: Clinical signs, hematological and biochemical alterations.] Investigação molecular de Ehrlichia spp. e Anaplasma platys em felinos domésticos: alterações clínicas, hematológicas e bioquímicas. Pesquisa Veterinária Brasileira 31(10):899-909. Laboratório de Clínica e Cirurgia Animal, Hospital Veterinário, Universidade Estadual do Norte Fluminense Darcy Ribeiro, Av. Alberto Lamego 2000, Parque Califórnia, Campos dos Goytacazes, RJ 28013-602, Brazil. E-mail: elisabetesales@gmail.com

Ehrlichia sp. and Anaplasma platys are Gram-negative micro-organisms, obligate intracellular parasites, residing in cytoplasmic vacuoles of leukocytes and platelets, found in peripheral blood or tissue. Few reports have been made about ehrlichiosis and anaplasmosis in cats in Brazil, which are based on the presence of morulae in leukocytes and platelets, or by detecting antibodies. The objective of this study was to investigate the natural infection with Ehrlichia sp. and A. platys in cats in Campos dos Goytacazes-RJ, by hematoscopia and DNA detection of these agents. Samples of whole blood and serum from 91 cats, regardless of race, gender and age. Blood count, serum biochemistry and PCR using primers for Ehrlichia sp. and A. platys were perfomed. Data from hematoscopia showed $9.89 \%$ of morulae only in platelets. The DNA of $A$. platys was detected in $13.18 \%$ of the 91 samples and $44.44 \%$ of the positive at hematoscopia. The DNA of Ehrlichia sp. was not detected in any sample. All animals studied did not show clinical signs neither positive laboratory results. The data suggest that domestic cats can serve as potential reservoirs for A. platys as asymptomatic form of related diseases.
\end{abstract}

INDEX TERMS: Anaplasma platys, Ehrlichia sp., domestic cats, PCR.

RESUMO.- Ehrlichia sp. e Anaplasma platys são micro-organismos Gram negativos, parasitos intracelulares obrigatórios, residindo em vacúolos citoplasmáticos de leucócitos e plaquetas, encontrados no sangue periférico ou em tecidos. Poucos relatos têm sido feitos sobre erliquiose e anaplasmose em gatos no Brasil, os quais são baseados na

\footnotetext{
${ }^{1}$ Recebido em 4 de julho de 2011.

Aceito para publicação em 16 de agosto de 2011.

${ }^{2}$ Laboratório de Clínica e Cirurgia Animal, Hospital Veterinário, Universidade Estadual do Norte Fluminense Darcy Ribeiro (UENF), Av. Alberto Lamego 2000, Parque Califórnia, Campos dos Goytacazes, RJ 28013-602, Brasil.*Autor para correspondência: elisabetesales@gmail.com

${ }^{3}$ Laboratório de Patologia Clínica Veterinária, Faculdade de Agronomia e Medicina Veterinária, Universidade de Brasília (UNB), SGAN 605, Av. L2 Norte, Brasília, DF 70910-900, Brasil.
}

presença de mórulas em leucócitos e plaquetas, ou pela detecção de anticorpos. 0 objetivo deste trabalho foi investigar a infecção natural por Ehrlichia sp. e A.platys em gatos no Município de Campos dos Goytacazes-RJ, através da hematoscopia e pela detecção do DNA desses agentes. Foram utilizadas amostras de sangue total e de soro de 91 gatos, independente de raça, sexo e idade. Realizaram-se hemograma, bioquímica sérica e PCR, utilizando oligonucleotídes para Ehrlichia sp. e A.platys. Os dados de hematoscopia mostraram que $9,89 \%$ dos gatos apresentaram mórulas em macroplaquetas. 0 DNA de A.platys foi detectado em $13,18 \%$ dos 91 animais e em 44,44\% das amostras positivas à hematoscopia. O DNA de Ehrlichia sp. não foi detectado em nenhuma amostra. Nenhuma alteração foi observada nos sinais clínicos nem nos resultados labo- 
ratoriais nos animais estudados. Os dados sugerem que os felinos domésticos podem atuar como potenciais reservatórios para A. platys, como forma não sintomática das enfermidades relacionadas.

TERMOS DE INDEXAÇÃO: Anaplasma platys, Ehrlichia sp., felinos domésticos, PCR.

\section{INTRODUÇÃO}

No Brasil, com exceção dos hemoplasmas, os hemoparasitas de gatos são pouco conhecidos, existindo somente relatos esporádicos de Ehrlichia spp. (Almosny \& Massard 2002). A natureza inespecífica dos sinais clínicos em gatos infectados associada à baixa sensibilidade e especificidade da técnica do esfregaço sangüíneo podem ter resultado no subdiagnóstico desses parasitas no Brasil (Oliveira 2008). Apesar disso, são poucos os relatos envolvendo biologia molecular no diagnóstico das hemoparasitoses de felinos no mundo (Almosny 1998).

Mas é necessário ressaltar que, apesar da escassez de conhecimento sobre o assunto, da falta de relatos e de realização do diagnóstico, a infecção em gatos por Ehrlichia spp. e Anaplasma spp. existe no Brasil (Almosny \& Massard 2002, Santarém et al. 2005, Oliveira 2008, Lima et al. 2010) e estes agentes estão presentes como parasitas potenciais e devem receber mais atenção por parte dos médicos veterinários e_sobretudo, pesquisadores (Lima et al. 2010).

Os vetores da erliquiose felina não são conhecidos e também, ainda não estão definidas as vias de transmissão da infecção natural, sendo provável que a exposição a artrópodes e ingestão de roedores seriam as principais causas de contaminação dos felinos naturalmente infectados (D’Agnone et al. 2001).

Nos últimos anos houve um maior avanço no entendimento das infecções transmitidas por carrapatos devido à aplicação de técnicas moleculares, em particular a Reação em Cadeia da Polimerase (PCR), utilizadas no diagnóstico e identificação desses agentes. As recentes pesquisas envolvendo biologia molecular e agentes Rickettsiais confirmam a idéia de que esses parasitas estão presentes nesses animais e demonstram a necessidade de estudos mais detalhados sobre esses agentes no Brasil (Lima et al. 2010).

A anaplasmose e a erliquiose são transmitidas por vetores. A distribuição geográfica destes tem uma influência direta sobre a prevalência da doença em uma determinada área (Hinrichsen et al. 2001). Infecções por Ehrlichia spp. e Anaplasma spp. ocorrem pela saliva, através da picada do carrapato em animais ou humanos (Madigan et al. 2000). Diferentes espécies de carrapatos estão associadas com determinadas espécies de Ehrlichia. Assim, E. canis e A. platys são transmitidos pelo carrapato Rhipicephalus sanguineus, que por sua vez pode transmitir o agente $E$. ewingii (Cohn 2003). Carrapatos Ixodes spp. mais frequentemente transmitem A. phagocytophilum, enquanto Amblyomma spp. e Dermacentor spp. são conhecidos portadores de E. chaffeensis e E. ewingii (Preziosi \& Cohn 2002). Experimentalmente, E. canis também pode ser transmitida pelo carrapato Dermacentor sp. (Johnson et al. 1998).
0 mesmo vetor pode albergar diversos agentes e, por sua vez, diferentes espécies de carrapatos podem infectar o mesmo animal, sendo responsável por infecções de diferentes agentes patogênicos no mesmo hospedeiro, resultando em co-infecções que dificultam o diagnóstico e tratamento da doença (Breitschwerdt et al. 1998). No entanto, tem sido sugerido que a co-infecção por diferentes agentes não altera o curso da doença (Mylonakis et al. 2004). Apesar disso, alguns autores consideram que, em geral, um único agente parece ser mais comum do que vários agentes simultaneamente (Belongia 2002).

Sabe-se que os gatos parecem ser menos predispostos às infestações por carrapatos e aos parasitas transmitidos por esses artrópodes do que os cães (Shaw et al. 2005). Além disso, esses animais têm uma suposta resistência inata ou adaptação às infecções, o que limita o desenvolvimento das doenças ou compromete a transmissão de agentes infecciosos entre carrapatos e gatos (Shaw et al. 2005).

0 presente estudo teve como objetivo investigar a existência da infecção por Ehrlichia sp. e Anaplasma platys em felinos domésticos no Município de Campos dos Goytacazes-RJ, por meio de esfregaços sanguíneos e da Reação em Cadeia pela Polimerase (PCR) relacionando com as alterações clínico-laboratoriais. Ainda, objetivou-se comparar os resultados obtidos pela PCR com a hematoscopia.

\section{MATERIAL E MÉTODOS}

0 presente estudo foi licenciado de acordo com as normas e princípios éticos de experimentação animal estabelecidos pela Comissão de Ética de Uso de Animais (CEUA) da Universidade Estadual do Norte Fluminense Darcy Ribeiro, aprovado com registro $78 / 2009$.

Foram amostrados 91 gatos, sem restrição de idade, raça ou sexo, oriundos da rotina ambulatorial do Hospital Veterinário da UENF. Sob contenção física, a coleta sanguinea foi realizada por meio de venopunção cefálica ou jugular. Uma alíquota foi separada em tubos contendo ácido etilenodiaminotetracético (EDTA) para realização do hemograma e PCR, e a outra aliquota em tubos siliconados para a realização de testes bioquímicos.

Colheu-se sangue periférico obtido a partir da punção de capilar marginal de ponta de orelha de cada animal, aproveitando apenas a primeira gota de sangue, para a confecção de esfregaços sanguíneos finos, que foram corados pelo método panótico rápido e posteriormente visualizados a microscopia óptica com objetiva de imersão em aumento de $1.000 x$, à procura de corpúsculos elementares (iniciais ou mórulas) em leucócitos e plaquetas, sugestivos de Rickettsiales.

0 hemograma foi realizado em equipamento automatizado da marca Mindray®, modelo BC 2800 Vet. Para a realização dos exames bioquímicos, o material foi centrifugado a $1,26 \times 10^{4} \mathrm{~g}$ por cinco minutos e os testes bioquímicos foram realizados em equipamento automatizado da marca Bayer $\AA$, modelo Express plus, utilizando-se kits da marca Labtest $($. Foram avaliadas proteínas totais, albumina, fosfatase alcalina (FA), gamaglutamiltransferase (GGT), alanina aminotransferase (ALT), uréia e creatinina.

As amostras sanguineas destinadas a PCR foram processadas no Laboratório de Microbiologia e Patologia Molecular da UnB. 0 DNA foi extraído utilizando-se kits comerciais (Kit GE Healthcare® - Illustra blood genomicPrep Mini Spin kit), seguindo as recomendações do fabricante. As amostras de DNA foram mantidas a $-20^{\circ} \mathrm{C}$ até o momento da realização das PCRs. 
Nas reações em cadeia de polimerase (PCR) foram utilizados controles negativos e positivos para avaliar a ocorrência de contaminação de reagentes e a sensibilidade da reação, respectivamente. Como controle negativo, foi utilizado água ultra pura (MilliQ®) e como controle positivo foi utilizado DNA de Ehrlichia spp e Anaplasma platys obtidos de amostra sanguínea de um animal infectado com os agentes em questão. No início da padronização de cada reação, utilizou-se, além da água, amostra de DNA de um gato hígido como controle negativo para avaliar a especificidade da mesma. As reações foram realizadas em termociclador (Biorad®).

Todas as amostras foram submetidas a uma PCR para testar a qualidade da extração do DNA e reduzir a quantidade de falsos negativos devido à presença de inibidores da PCR. Para isto foram utilizados os oligonucleotídeos GAPDH-F (5'-CCT TCA TTG ACC TCA ACT ACA T-3') e GAPDH-R (5'-CCA AAG TTG TCA TGG ATGACC-3') que anelam em uma seqüência específica do gene da enzima gliceraldeído 3-fosfato desidrogenase e resulta em um produto de $400 \mathrm{pb}$ (Birkenheuer et al. 2003).

Foram utilizados os oligonucleotideos DSB (gene disulfide Bond protein); Dsb-330 ( 5'-GATGATGTCTGAAGATATGAAACAAAT-3') e Dsb-728 (5'-CTGCTCGTCTATTTACTTCTTAAAGT-3') que anelam no gene 16S rRNA e resultam em produtos que variam entre 411-421pb dependendo da espécie de Ehrlichia sp. envolvida. Os oligonucleotídeos do Gene Dsb amplificam o DNA das principais espécies de Ehrlichias conhecidas: Ehrlichia chaffeensis, Ehrlichia ewingii e Ehrlichia canis, conforme Doyle et al. (2005).

Para a identificação de $A$. platys foi utilizada a nested polymerase chain reaction (nPCR) foi realizada como descrito por Martin et al. (2005), usando oligonucleotídeos 8F ( 5' AGT TTG ATC ATG GCT CAG 3') e 1448R (5' CCA TGG CGT GAC GGG CAG TGT G 3'), que amplifica a maior parte do gene 16S rRNA (Dawson et al. 1996), na primeira etapa da PCR. Em seguida foi realizado uma segunda etapa usando um oligonuclotídeo específico para A.platys, PLATYSF (5' GAT TTT TGT CGT AGC TTG CTA TG 3') e um oligonuclotídeo específico para o gênero Ehrlichia sp. EHR16SR (5' TAG CAC TCA TCG TTT ACA GC 3') que produz um produto de $678 \mathrm{pb}$.

Para a análise dos dados foi utilizado o método de amostragem simples ao acaso, em proporções ou porcentagem no nível de 5\% de significância. As comparações foram feitas com base na sobreposição ou não dos intervalos de confiança (probabilidade de conter a proporção na população igual a 95\%), após dimensionamento da amostra para uma população infinita de ocorrências, considerando-se $\alpha=0,05$ e um desvio em torno da proporção amostral de $10 \%(\mathrm{~d}=0,10 \mathrm{p})$.

0 aplicativo computacional foi o SAEG, versão 9.0, de 2008 e para as tabelas de contingência 2 × 2 utilizou-se o Teste de Qui-quadrado ou o Teste Exato de Fisher, através do programa StatPlus 2009 Professional. As diferenças foram consideradas significativas quando $\mathrm{p} \leq 0,05$.

\section{RESULTADOS}

Foram utilizados no experimento 91 amostras de sangue de gatos, sendo 85 sem raça definida (SRD), quatro Siameses e dois da raça Persa. Destes 33 gatos $(36,26 \%)$ eram machos e 58 fêmeas $(63,74 \%)$, com idades variando de quatro meses a 15 anos de idade.

0 exame clínico realizado no momento da coleta das amostras de sangue revelou 56,04\% (51/91) dos gatos não apresentaram qualquer sinal de doença aparente a $5 \%$ de probabilidade, sendo que 34 gatos desse grupo de assintomáticos foram levados ao hospital para cirurgias eletivas de este- rilização. 43,96\% (40/91) dos animais aprestaram algum tipo de alteração clínica no momento da coleta das amostras não havendo diferença significativa a $5 \%$ de probabilidade.

Diferentes patologias foram observadas nos animais do grupo de gatos sintomáticos, sendo que a presença de febre foi o sinal clínico mais observado (45\%), seguida por alterações dermatológicas $(32,5 \%)$ e alterações digestivas (15\%) dentre outras.

0 Quadro 1 relaciona a frequência das principais alterações clínicas apresentadas pelos gatos pertencentes ao grupo dos animais sintomáticos.

\section{Quadro 1. Frequência das alterações clínicas dos gatos pertencentes ao grupo dos "Animais sintomáticos"}

\begin{tabular}{lcc}
\hline Alterações clínicas & $\begin{array}{c}\text { Número de animais/total } \\
\text { de animais sintomáticos }\end{array}$ & $\%$ \\
\hline Febre & $18 / 40$ & 45,0 \\
Neoplasia & $2 / 40$ & 5,0 \\
Inapetência e apatia & $2 / 40$ & 5,0 \\
Cistite & $2 / 40$ & 5,0 \\
Dermatopatias & $13 / 40$ & 32,5 \\
Diarréia & $6 / 40$ & 15,0 \\
Obstrução do TUI & $3 / 40$ & 7,5 \\
Lesão por trauma & $2 / 40$ & 5,0 \\
Otite & $3 / 40$ & 7,5 \\
Piometra & $3 / 40$ & 7,5 \\
Urolitíase & $1 / 40$ & 2,5 \\
Pneumonia & $2 / 40$ & 5,0 \\
Rinotraqueíte & $1 / 40$ & 2,5
\end{tabular}

Na pesquisa de hemoparasitas à hematoscopia, $9,89 \%$ (9/91) de mórulas foram observadas em plaquetas das amostras (Fig.1). Nas amostras positivas, as inclusões basofílicas foram observadas em menos de $1 \%$ das plaquetas, reiterando a baixa parasitemia. As plaquetas parasitadas se apresentavam como macroplaquetas. Nenhuma célula da linhagem leucocitária apresentou inclusões basofílicas sugestivas de agentes Rickettsiais.

Todas as amostras testadas na PCR com os oligonucleotídeos GAPDH-F e GAPDH-R, que amplificam uma parte do gene da enzima gliceraldeído 3-fosfato desidrogenase,

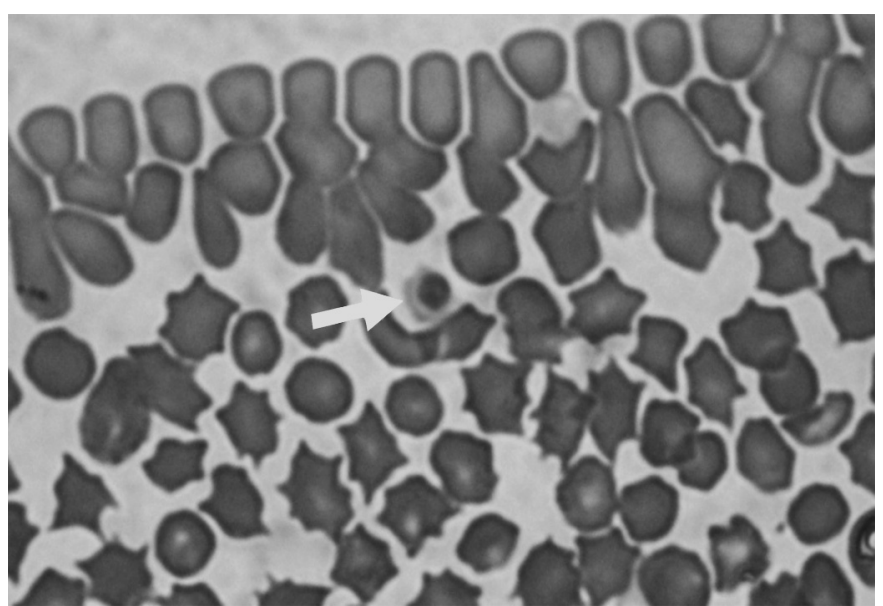

Fig.1. Inclusão basofílica em plaqueta de felino doméstico (seta). Panótico, 100x. UENF, 2010. 
apresentaram um produto com $400 \mathrm{pb}$, o que determina o êxito nas extrações de DNA das amostras sanguíneas dos gatos deste estudo (Fig.2).

Na PCR, utilizando-se os oligonucleotídeos Dsb-330 e Dsb-728 não foram observados produtos nos tamanhos entre 411 e $421 \mathrm{pb}$, que anelam no gene 16S rRNA que amplificam as principais espécies de erlíquias conhecidas (Ehrlichia chaffeensis, Ehrlichia ewingii e Ehrlichia canis) em nenhuma das amostras estudadas (Fig.3).

$\mathrm{Na}$ nested PCR foram detectados Anaplasma platys utilizando-se os oligonucleotídeos 8F, 1448R, Platys e EHR 16SR em uma proporção de 0.1318 (12/91) com IC entre 0,0609 e 0,2029 nas amostras dos gatos pesquisados, cujos produtos amplificados apresentavam tamanho de $678 \mathrm{pb}$, conforme o local de anelamento destes oligonucleotídeos no gene 16S rRNA da espécie Anaplasma platys (Fig.4).

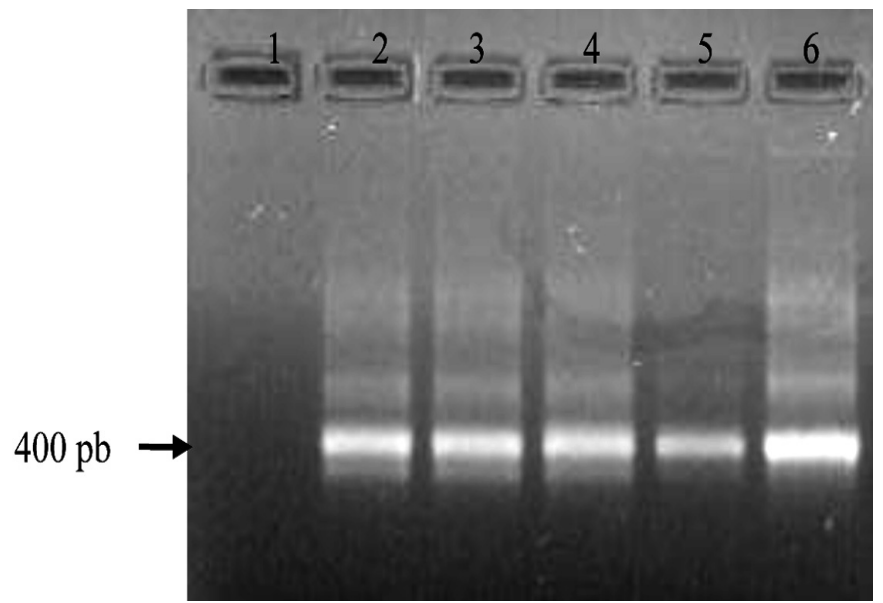

Fig.2. Eletroforese do produto da PCR utilizando os oligonucleotídeos GAPDH-F e GAPDH-R. Legenda: (1) controle negativo (água), (2) controle positivo, (3-6) animais positivos. Gel de agarose a $1,5 \%(\mathrm{p} / \mathrm{v})$ corado com brometo de etídeo a $0,01 \%$ (p/v). UNB, 2010.

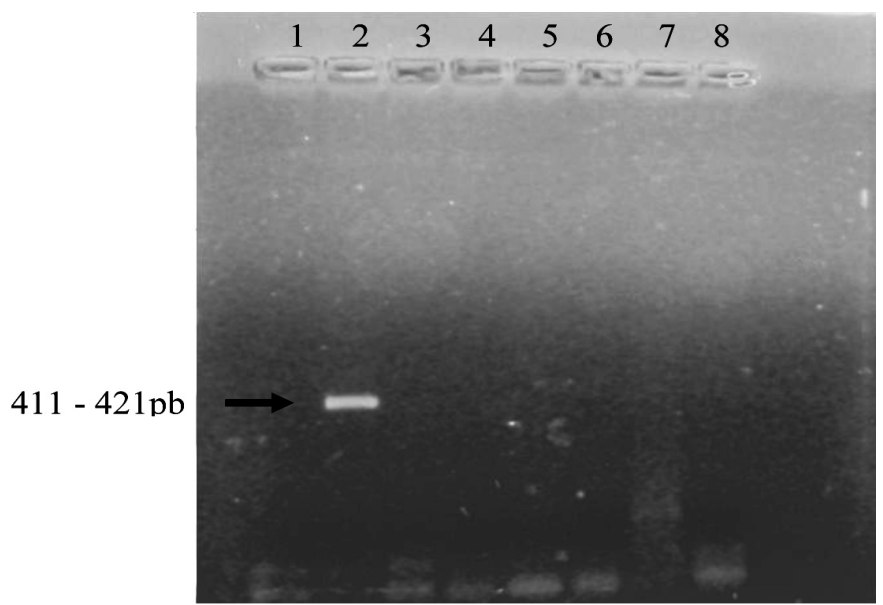

Fig.3. Eletroforese do produto da PCR utilizando os oligonucleotídeos Dsb-330 e Dsb-728. Amostra 1 = controle negativo (água), Amostra 2 = controle positivo, Amostras 3-8 representam animais negativos para infecção Ehrlichia chaffeensis, Ehrlichia ewingii e Ehrlichia canis. Gel de agarose a 1\% corado com brometo de etídeo a 0,01\% (p/v). UNB, 2010.

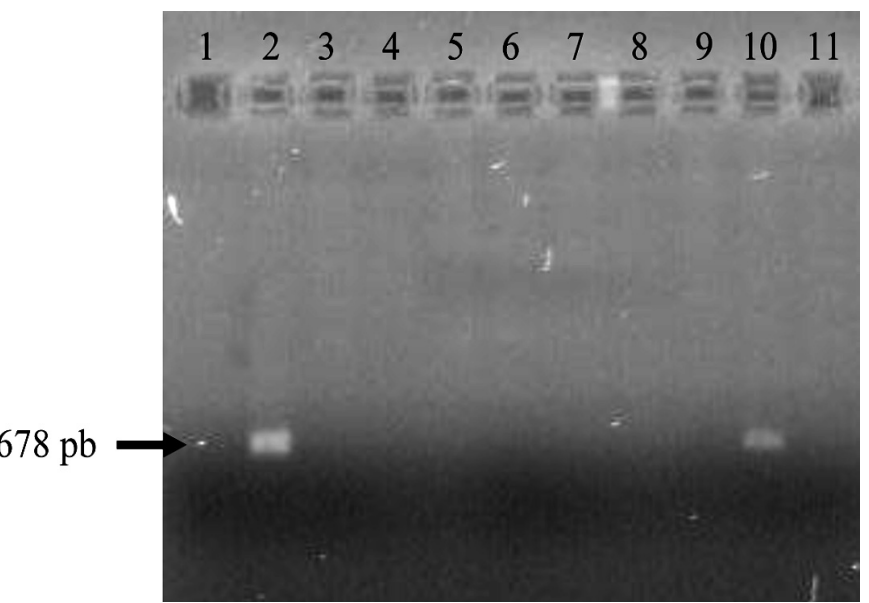

Fig.4. Eletroforese do produto da nPCR para a espécie Anaplasma platys, utilizando os oligonucleotídeos 8F, 1448R, Platys e EHR 16SR. Legenda: 1 = controle negativo (água), 2 = controle positivo, 3-9 e 11 = animais negativos, 10 = animal positivo. Gel de agarose a 1,5\% corado com brometo de etídeo a $0,01 \%$ (p/v). UNB, 2010.

O Quadro 2 apresenta a proporção e os limites inferiores e superiores do intervalo de confiança da média populacional dos animais positivos e negativos para Anaplasma platys no total de amostras sanguíneas dos gatos pesquisados. Como os IC para os animais positivos e negativos não estão superpostos conclui-se que as médias são estatisticamente diferentes ao nível de $5 \%$ de probabilidade.

Quadro 2. Proporção e limites inferiores e superiores do intervalo de confiança da média populacional dos animais positivos e negativos para Anaplasma platys (oligonucleotídeos 8F, 1448R, Platys e EHR 16SR)

\begin{tabular}{ccc}
\hline Animais & \multicolumn{2}{c}{ Total } \\
\cline { 2 - 3 } & \multicolumn{2}{c}{ Proporção } \\
\cline { 2 - 3 } & $0,1319(\mathrm{Pt})$ & IC \\
\hline Positivos & $0,8681(\mathrm{n}=79)$ & 0,0609 a $0,2029^{*}$ \\
Negativos & $1,0(\mathrm{n}=91)$ & 0 a 1,0 \\
Total & 0
\end{tabular}

* Estatisticamente diferentes ao nível de 5\% de probabilidade.

A proporção de animais positivos e negativos para agentes Anaplasma platys e seus respectivos limites inferiores e superiores do intervalo de confiança, observados utilizando testes de pesquisa direta: esfregaço sanguíneo e nPCR para Anaplasma platys são apresentados no Quadro 3 e não demonstram diferença significativa $(p>0,05)$. Somente quatro animais que apresentaram mórulas em macroplaquetas no esfregaço sanguíneo também foram positivos na nPCR para Anaplasma platys.

As alterações hematológicas: anemia, leucopenia, leucocitose e trombocitopenia, não foram relacionadas à doença, dado que a prevalência de $A$. platys foi três vezes menor em gatos com trombocitopenia, cinco vezes menor em gatos com anemia e leucopenia e 10 vezes menor em gatos com 
Quadro 3. Proporção e limites inferiores e superiores do intervalo de confiança das médias populacionais dos animais positivos no esfregaço sanguíneo e positivos para Anaplasma platys na nPCR

\begin{tabular}{|c|c|c|c|c|}
\hline & \multicolumn{4}{|c|}{ Testes } \\
\hline & \multicolumn{2}{|c|}{ PCR } & \multicolumn{2}{|c|}{ Esfregaço sanguíneo } \\
\hline & Proporção & IC & Proporção & IC \\
\hline Positivo & $0,1319(n=12)$ & 0,0609 a 0,2029 Ns & $0,0989(n=9)$ & 0,0363 a $0,1615^{\mathrm{NS}}$ \\
\hline Negativo & $0,8681(n=79)$ & 0,7971 a 0,9391 Ns & $0,9011(n=82)$ & 0,8385 a 0,9637 Ns \\
\hline Total & $1,0(n=91)$ & 0 a 1,0 & $1,0(n=91)$ & 0 a 1,0 \\
\hline
\end{tabular}

${ }^{\mathrm{Ns}}$ Estatisticamente iguais ao nível de $5 \%$ de probabilidade.

leucocitose (Quadro 4). Não houve diferença $(P>0,05)$ entre a presença ou não de $A$. platys e a presença de anemia, trombocitopenia e alterações leucocitárias, seja leucopenia ou leucocitose.

Os resultados das análises estatísticas dos hemogramas e análises bioquímicas dos animais positivos e negativos para A. platys, estão apresentados no quadro cinco.

No hemograma observa-se que não houve superposição entre as médias de neutrófilos para os grupos de animais positivos e negativos, mas para ambos os grupos, permanecem dentro dos valores de referência para a espécie felina. Entretanto, conclui-se que o intervalo de confiança das médias de neutrófilos entre os grupos positivos e negativos para A. platys é estatisticamente diferente ao nível de 5\% de probabilidade. Para os outros caracteres, observou-se superposição entre os IC das médias de proporção entre os grupos de animais positivos e negativos para A. platys, portanto, estatisticamente as médias das proporções dos caracteres do hemograma, com exceção dos neutrófilos, são iguais a $5 \%$ de probabilidade. Para os gatos positivos, o limite inferior do IC da média para plaquetas ficou abaixo do limite inferior dos valores de referência. Para os gatos negativos, o limite superior do IC da média das proporções para os eosinófilos e bastões superou os valores de referência para esses caracteres.

Para os caracteres testados na bioquímica sérica, somente a creatinina obteve média igual a zero, sendo assim não houve superposição entre as médias de creatinina para

Quadro 4. Dados hematológicos (n=91) e comparação com resultado da PCR de gatos atendidos no Hospital Veterinário da UENF, independente do estado de saúde e testados para Anaplasma platys

\begin{tabular}{lcc}
\hline \multicolumn{1}{c}{ Dados hematológicos (número) } & \multicolumn{2}{c}{ PCR A. platys, número (\%) } \\
\cline { 2 - 3 } & Positivo & Negativo \\
\hline I. Anêmicos $^{\mathrm{E}}(5)$ & $2(40 \%)^{\mathrm{a}}$ & $3(60 \%)$ \\
II. Não-anêmicos (86) $^{\mathrm{a}}$ & $10(11,63 \%)$ & $76(88,37 \%)$ \\
III. Trombocitopênicos $^{\mathrm{E}}(28)$ & $3(10,71 \%)^{\mathrm{b}}$ & $25(89,29 \%)$ \\
IV. Não-trombocitopênicos (63) & $9(14,29 \%)$ & $54(85,71 \%)$ \\
V. Leucopenia $^{\mathrm{E}}(3)$ & $2^{\mathrm{c}}$ & 1 \\
VI. Leucocitose $^{\mathrm{E}}(17)$ & $0^{\mathrm{d}}$ & 17 \\
VII. Sem alterações leucocitárias $(71)^{\text {cd }}$ & $10^{\text {cd }}$ & 61
\end{tabular}

a $P>0,05$ para o grupo I versus II (teste de Fisher), ${ }^{\mathrm{b}} P>0,05$ para o grupo III versus IV (teste de Fisher), ${ }^{\mathrm{c}} P>0,05$ para o grupo V e VII (teste de Fisher), ${ }^{\text {d }} P>0,05$ para os grupos VI e VII (teste de Fisher), ${ }^{\mathrm{E}}$ Valores de referência: Jain (1993).
Quadro 5. Limites inferiores e superiores do Intervalo de Confiança da média populacional dos caracteres do hemograma e das análises de bioquímicas sérica apresentados pelos animais positivos e negativos para Anaplasma platys

\begin{tabular}{|c|c|c|c|}
\hline \multirow[t]{2}{*}{ Parâmetros } & \multicolumn{3}{|c|}{ Total de animais $(\mathrm{n}=91)$} \\
\hline & $\begin{array}{c}\text { Positivos } \\
(\mathrm{n}=12)\end{array}$ & $\begin{array}{c}\text { Negativos } \\
(\mathrm{n}=79)\end{array}$ & $\begin{array}{l}\text { Valores de } \\
\text { referência }\end{array}$ \\
\hline Hemácias $\left(\times 10^{6} / \mu \mathrm{L}\right)$ & $5,81-9,04$ & $7,86-8,64$ & $5,0-10,0$ \\
\hline VG \% & $24,99-39,71$ & $33,67-37,00$ & $24,0-45,0$ \\
\hline Hemoglobina $(\mathrm{g} / \mathrm{dL})$ & $8,59-13,66$ & $11,63-12,79$ & $8,0-15,0$ \\
\hline VCM (fL) & $41,63-45,05$ & $41,89-44,22$ & $39,0-55,0$ \\
\hline 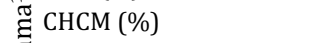 & $33,80-34,85$ & $34,36-34,90$ & $30,0-36,0$ \\
\hline$\widetilde{T}_{0}^{\pi}$ Plaquetas $\left(\mathrm{x} 10^{3} / \mu \mathrm{L}\right)$ & $139,80-316,03$ & 225,82 - 289,16 & $175,0-500,0$ \\
\hline Leucócitos totais $\left(\mathrm{X} 10^{3} / \mu \mathrm{L}\right)$ & $8,08-14,50$ & $14,06-17,65$ & $5,50-19,50$ \\
\hline ฮี Eosinófilos $(\mu \mathrm{L})$ & $393,51-969,82$ & $996,37-1531,15$ & $0,0-1500,0$ \\
\hline Bastonetes $(\mu \mathrm{L})$ & $64,94-296,40$ & 156,21 - 489,05 & $0,0-300,0$ \\
\hline Neutrófilos $\left(\mathrm{X} 10^{3} / \mu \mathrm{L}\right) *$ & $4,11-8,09$ & $8,88-11,35$ & $2,50-12,50$ \\
\hline Linfócitos $\left(\mathrm{X} 10^{3} / \mu \mathrm{L}\right)$ & $1,60-6,51$ & $2,98-$ & $1,50-7,00$ \\
\hline Monócitos $(\mu \mathrm{L})$ & $153,05-354,12$ & $351,60-527,90$ & $0,0-850,0$ \\
\hline Uréia (mg/dL) & $43,79-70,01$ & $47,30-63,34$ & $42,80-64,20$ \\
\hline ₹ Creatinina $(\mathrm{mg} / \mathrm{dL}) *$ & 0 & $0,95-1,99$ & $0,80-1,80$ \\
\hline$\stackrel{\mathscr{U}}{\leftrightarrows} \operatorname{ALT}(\mathrm{UI} / \mathrm{L})$ & $1,49-94,72$ & $37,48-55,46$ & $6,00-83,00$ \\
\hline$\underbrace{\infty}_{\infty} \mathrm{AST}(\mathrm{UI} / \mathrm{L})$ & $15,85-33,26$ & $32,19-42,83$ & $26,00-43,00$ \\
\hline : FA (UI/L) & $22,75-49,04$ & $37,15-50,32$ & $25,00-93,00$ \\
\hline 可 GGT & $1,66-3,87$ & $2,56-3,67$ & $1,30-5,10$ \\
\hline Б्ठPT sérica & $6,21-10,57$ & $6,72-7,33$ & $5,40-7,80$ \\
\hline Albun & $2,23-3,21$ & $2,46-2,81$ & $2,10-3,30$ \\
\hline Globulina (g/dL) & $3,80-7,54$ & $4,08-4,70$ & $2,60-5,10$ \\
\hline
\end{tabular}

* Diferença estatística, ao nível de $5 \%$ de probabilidade entre os grupos sintomáticos e assintomáticos. Legenda: Volume globular (VG), Volume Corpuscular Médio (VCM), Concentração de Hemoglobina Corpuscular Média (CHCM), Alanina aminotransferase (ALT) Aspartato aminotransferase (AST), Fosfatase alcalina (FA), Gama glutamil transferase (GGT), Proteína total (PT). Fontes de Valores de Referência: Lopes et al. (2007) ${ }^{1}$, Meyer et al. (1995) ${ }^{1}$ e Kaneko et al. (2008) 2 .

os grupos de animais positivos e negativos, o que conclui serem grupos estatisticamente diferentes ao nível de $5 \%$ de probabilidade. Para o grupo de animais negativos para A. platys, o limite superior do IC da proporção da média de creatinina foi maior que o limite máximo aceito na referência teórica utilizada neste estudo. Os outros caracteres testados na bioquímica sérica apresentaram superposição entre os IC das proporções das médias, sendo iguais estatisticamente ao nível de $5 \%$ de probabilidade. Os limites inferiores dos IC das proporções das médias de ALT, AST e FA se apresentaram abaixo dos níveis mínimos dos valores de referencia para os gatos positivos para A. platys. Entretanto para Uréia, ALT, proteína total e globulinas apresentaram limites superiores dos IC das proporções das médias, acima 
devido ao potencial zoonótico dos agentes e da possibilidade de infestação humana por carrapatos e outros ectoparasitas dos animais (Tamí \& Tamí-Maury 2004, De La Fuente et al. 2005, Dantas-Torres et al. 2006).

Neste estudo, foram pesquisadas em felinos domésticos, a partir do diagnóstico molecular, do gênero Ehrlichia spp. as espécies: E. canis, E. chaffeensis e E. ewingii, e, do gênero Anaplasma, apenas foi investigada a espécie Anaplasma platys. Por meio da pesquisa em esfregaço sanguíneo utilizando-se microscopia óptica foi avaliada a presença de hemocitozoários nos diferentes tipos celulares e comparado os resultados desta pesquisa com a PCR, ambas consideradas técnicas de pesquisa direta dos agentes Rickettsiais.

A não amplificação do DNA das espécies pertencentes aos gêneros Ehrlichia spp. observada neste trabalho, está de acordo com Aguirre et al. (2004) e Luria et al. (2004) que não detectaram o DNA de nenhuma espécie de Ehrlichia spp em amostras de sangue de 553 gatos domésticos na Florida. Este estudo também corrobora com os resultados de Lappin et al. (2005), que pesquisou 92 gatos e suas pulgas nos EUA sem detectar DNA erliquial. Da mesma forma Vita et al. (2005), e Eberhardt et al. (2006), também não amplificaram DNA de Ehrlichia canis em Abruzzo (Itália) e no Arizona, respectivamente; Em 47 gatos domésticos testados por Solano-Gallego et al. (2006), todas as amostras foram negativas para a presença do DNA de Ehrlichia spp. Santiago (2010) pesquisou 600 gatos em Madrid e região metropolitana, e da mesma forma não obteve êxito na detecção de Ehrlichia spp. tanto no sangue quanto em cultivos celulares. Alguns autores sugerem a falha na detecção devido a problemas de extração do DNA, o que não foi o motivo no presente estudo uma vez que todas as amostras foram positivas para a a enzima GAPDH,. No entanto, contrariando os resultados deste estudo, alguns autores obtiveram sucesso na amplificação de DNA de Ehrlichia spp. em gatos domésticos (Beaufils et al. 2002, Breitschwerdt et al. 2002, Yin-Chiachun et al. 2003, Oliveira 2008, Tabar et al. 2008, Georges et al. 2008) e em felinos selvagens onde André (2008) foi o pioneiro a detectar a presença de $E$. $c a$ nis em 11 felinos selvagens mantidos em zoológicos de São Paulo e Brasília. Breitschwerdt et al. (2002) detectaram DNA de E. canis em três felinos domésticos com manifestações clínicas de erliquiose, porém soronegativos frente ao antígeno de E. canis. Também, Yin-Chiachun et al. (2003) detectaram DNA de E. canis pela nested PCR em dois de 17 felinos domésticos analisados, os quais apresentavam-se soronegativos e anêmicos. Em Barcelona, Tabar et al. (2008) encontraram um único animal positivo na PCR para os gêneros Ehrlichia/Anaplasma entre 100 felinos domésticos. No Brasil, Oliveira (2008) relata a primeira detecção molecular de E. canis em 3 de 15 gatos pesquisados. Georges et al. (2008) pela primeira vez em Trinidad testaram 15 gatos domésticos e detectou o DNA de E.canis em um gato.

Neste estudo para as espécies do gênero Ehrlichia sp., foi utilizada a PCR convencional, ou seja, uma reação onde se amplifica o DNA pesquisado em uma única etapa de acordo com Alves et al. (2005); Doyle et al. (2005) e Inokuma et al. (2000) que pesquisaram essas espécies em cães, cuja parasitemia é maior que nos gatos Entretanto, segundo Wen et al. (1997), a nested PCR é altamente sensível, pois é capaz de detectar 0,2 pg de DNA purificado de E. canis, enquanto que uma só amplificação de DNA permite detectar apenas valores acima de $20 \mathrm{pg}$.

Após testar a nested PCR com primers baseados na seqüência do gene 16SrRNA da Ehrlichia spp. na primeira amplificação e primers específicos para $E$. canis na segunda etapa, Wen et al. (1997) inferiram que a nested PCR é altamente sensível e específica para a detecção de E. canis. Aguirre et al. (2008) relatam após comparar cinco protocolos diferentes de nPCR com uma PCR convencional, que a nPCR chega a ser 33\% mais eficiente para a detecção de E. canis. Ramos et al. (2009) também recomenda o nPCR para pesquisa de $E$. canis e A. platys pela maior sensibilidade e especificidade para detecção de ambos os patógenos. Entretanto, uma análise comparativa entre a PCR (gene DSB) e a nested-PCR (16S rRNA), realizada em 24 amostras sangüíneas de cães naturalmente infectados por E. canis, demonstrou que as duas técnicas são adequadas ao diagnóstico da erliquiose monocítica canina (Machado 2004). Outros alvos moleculares, específicos para a identificação de seqüências do DNA de E. canis e utilizados em PCR de etapa única, vêm demonstrando serem igualmente sensíveis e específicos em relação à técnica de nested-PCR, com as vantagens adicionais de reduzirem falsos-positivos devido à contaminação por produtos da PCR da primeira etapa, além de abreviar o tempo de execução (Alves et al. 2005; Marsílio et al. 2006; Vinasco et al. 2007). Doyle et al (2005), desenvolveram um protocolo de PCR em tempo real (real-time PCR) no qual é possível detectar e diferenciar importantes espécies de Ehrlichia em uma única reação de amplificação do gene $d s b$, com satisfatória sensibilidade analítica. A técnica foi capaz para distinguir as espécies $E$. chaffeensis, E. ewingii e E. canis, detectando também coinfecções em uma mesma amostra (Doyle et al. 2005). Sendo assim, o protocolo para reação de PCR, em uma única etapa de reação, avaliado neste trabalho, foi eficaz e específico para o diagnóstico de E. canis na espécie felina. Vale ressaltar que a parasitemia nesta espécie é bem menor que em cães, (Luria et al. 2004; Lappin et al. 2005, Shaw et al. 2005, Eberhardt et al. 2006) sendo imprescindível estabelecer o limiar de detecção das espécies erliquiais no sangue de felinos pelas técnicas de PCR em etapa única.

A realização de uma PCR, amplificando DNA de todas as espécies de Ehrlichia spp., seguida por seqüenciamento, é uma ferramenta útil para o estudo epidemiológico da infecção erliquial em carrapatos e vertebrados (Inokuma et al. 2001). Sempre que possível, fragmentos amplificados pela PCR devem ser seqüenciados para confirmar a validade dos resultados da PCR quando o ensaio está sendo feito para diferenciar espécies de Ehrlichia, particularmente quando a PCR é aplicada a amostras derivadas de outros animais que não cães (Hancock et al. 2001, Massung \& Slater 2003). Neste estudo não foi possível a realização do seqüenciamento, uma vez que não houve amplificação de DNA de espécies dos gêneros Ehrlichia sp.

Considerando que região de estudo (Campos dos Goytacazes) seja endêmica para a infecção por $E$. canis em cães (Albernaz et al. 2007), os autores supracitados sugerem 
que felinos são mais resistentes à infecção ou menos expostos a vetores apropriados que os cães, ou ainda que removam os vetores antes que a transmissão dos hemoparasitas ocorra (48 horas). Também é possível que os gatos deste estudo possuam menor número de cópias circulantes de DNA de Ehrlichia spp. que os cães, ou ainda, que a alíquota da amostra coletada não tivesse a presença de mórulas, gerando resultados falso-negativos (Luria et al. 2004, Lappin et al. 2005, Eberhardt et al. 2006). Segundo Shaw et al. (2005), felinos parecem ser menos predispostos que cães a certas doenças transmitidas por carrapatos, tais como erliquiose, babesiose e hepatozoonose e também questiona a possibilidade dos felinos apresentarem uma resistência inata ou adaptativa à infecção que limita o desenvolvimento da doença ou de certa forma, comprometem a transmissão de agentes pelos carrapatos. Pouco se conhece sobre as espécies de carrapatos capazes de infestar e transmitir doenças aos gatos.

Nos gatos desse estudo observou-se que no diagnostico direto, tanto no esfregaço sanguíneo como na pesquisa de DNA, a presença dos agentes causadores de infecção por bactérias pertencentes à Família Anaplasmataceae, são pouco freqüentes e independe da raça, idade, sexo ou da condição clinica dos animais, o que é corroborado por Almosny \& Massard (2002), que relatam que no Brasil, existe apenas a descrição de casos esporádicos de Ehrlichia sp. em felinos domésticos.

Quanto ao diagnóstico em esfregaços, Mylonakis et al. (2003) relatam que as alterações morfológicas nas células que podem ser parasitadas por E. canis e A. platys, podem gerar confusão durante a leitura na microscopia, especialmente em plaquetas que apresentam granulações densas ou resquícios nucleares de megacariócitos, assemelhando-se a mórula de $A$. platys. Outro fator importante é que mórulas de E. canis podem ser observadas em plaquetas como já foi descrito por Almosny (1998), podendo ser confundida com A. platys baseando-se na identificação morfológica do agente na célula parasitada. D’Agnone (2006) observou a presença de E. canis em plaquetas de dois cães por meio da nPCR. Sousa (2006) também observou mórulas de E. canis em plaquetas de dois cães e de E. canis e A. platys em outros dois cães de um total de 15 animais pesquisados por nPCR e Ramos et al. (2009) através da nPCR observaram que de quatro cães com mórulas em plaquetas, três eram E. canis e apenas uma amostra era $A$. platys. Neste estudo nenhuma das amostras positivas no esfregaço foram positivas para nenhuma espécie do gênero Ehrlichia sp, sendo necessário maiores investigações acerca da presença das inclusões nas plaquetas.

Entre as espécies do gênero Anaplasma foi investigada a espécie $A$. platys através da nested PCR utilizando os oligonucleotídeos 8F, 1448R, Platys e EHR 16SR, cuja proporção de amostras positivas foi de 0.1318 (12/91) com IC entre 0,0609 e 0,2029 nas amostras dos gatos pesquisados. A freqüência de gatos positivos para Anaplasma platys numa população infinita é estatisticamente significativa.

A verificação da $A$. platys obtida neste estudo vêm corroborar com Lima et al. (2010) que em Pernambuco, fizeram a primeira descrição molecular de $A$. platys em um gato macho de aproximadamente 10 anos, com anorexia, apatia, anúria e constipação. Na rotina clinica, com a realização de um hemograma observaram durante a contagem diferencial de leucócitos, que algumas plaquetas apresentavam mórulas compatíveis com $A$. platys e nenhuma outra alteração importante. Para a identificação molecular, Lima et al. (2010), utilizaram o mesmo protocolo de nested PCR utilizado neste estudo. Antes de Lima et al. (2010), Santarém et al. (2005) relataram pela primeira vez um caso de uma gata com anemia normocítica normocrômica, trombocitopenia e que apresentava mórulas em aproximadamente $7 \%$ das plaquetas tipo-Anaplasma platys.

Em felinos selvagens, Dahroug (2009) detectou por nPCR o DNA de $A$. platys em uma onça parda de cativeiro e se apresentava sadia e sem alterações fisiológicas ao exame físico e ao hemograma.

Não existem outros relatos desta parasitose em felinos domésticos ou selvagens, de uma maneira geral, sugerindo ser este o primeiro estudo epidemiológico da Rickettsiose felina por $A$. platys. No entanto, relatos de infecções por outras espécies do gênero Anaplasma são reportados. Para Anaplasma phagocytophilum, as taxas de soro prevalência encontradas variaram de 1,8\% a 4,3\% em felinos domésticos (Bjoersdorff et al. 1999; Lappin et al. 2004; Solano-Gallego et al. 2006; Billeter et al. 2007). 0 método molecular também é descrito como ferramenta para detecção da infecção por Anaplasma phagocytophilum em felinos (Lappin et al. 2005, Shaw et al. 2005, Solano-Gallego et al. 2006, Tabar et al. 2008, Otranto \& Dantas-Torres 2010, Santiago 2010).

Nenhuma publicação descreveu até agora o modo de transmissão desses agentes no gato. Por um lado, tem-se responsabilizado o carrapato, por serem os vetores desses agentes nos cães, o que sugere que no gato tambem sejam transmitidos pela picada do mesmo. Carrapatos infectados com mórulas compatíveis de Ehrlichia / Anaplasma spp. também foram encontrados em gatos (Buoro et al. 1989, Bjöersdorf et al. 1999, Tarello 2005, Otranto \& Dantas-Torres, 2010). No entanto há descrição de casos de infecão por esses agentes nos felinos sem exposição á artrópodes (Charpentier et al. 1986, Bouloy et al. 1994, Beaufils et al. 1995, 1999). Além disso, a transmissão tem sido associada á pulgas, por serem vetores presentes em gatos com suspeita de infecção por Ehrlichia spp. (Peavy et al. 1997). Outra possibilidade é a aquisição destes agentes por comer roedores infectados, como no caso de Coxiella burnetii (Kordick et al. 1995) ou pelo contato com os artrópodes que se alimentam de roedores (Kawahara et al. 1993, Nicholson et al. 1998). Entretanto, o aumento dos relatos de casos de infecções por esses agentes nestes animais reforça a necessidade de maiores estudos para definir quais as espécies infectam gatos e qual a participação deles na epidemiologia das erliquioses.

Como descrito anteriormente, não foram encontrados carrapatos nos gatos desse estudo, mas pulgas e pilhos foram identificados em 71,43\% (65/91) mas sem associação com a presença do DNA de $A$. platys. Este resultado está de acordo com os resultados obtidos por Santiago (2010) que obteve soro reatividade para alguns agentes Rickettsiais $(E$. 
canis, A. phagocitophilum, N. risticii) em gatos com ectoparasitos, porém estatisticamente não associou a presença de pulgas e carrapatos, com as Rickettsioses felinas.

Ferreira et al. (2007) compararam a análise morfológica por meio do esfregaço sanguíneo com os resultados da análise molecular (PCR) e observaram que não houve diferença significativa $(p>0,05)$ entre os testes, o que indica que a análise do esfregaço de sangue é uma boa alternativa para o diagnóstico $A$. platys, dados esses que também foram observados neste estudo. A possibilidade da utilização da PCR, por esses autores, não foi descartada, por ser um teste altamente específico. A chance de um falso-negativo entre os animais PCR-negativo existe, já que uma quantidade reduzida de microrganismos pode causar a inflamação e o aparecimento de corpos de inclusão inespecíficos que podem não ser suficientes para serem detectáveis.

Por outro lado, devido à natureza cíclica da doença, visualizar o microorganismo no interior das plaquetas de animais doentes não é uma tarefa fácil, e é geralmente um achado acidental. Isso pode ser explicado por uma diminuição da contagem de plaquetas durante a infecção e, conseqüentemente, diminuição do número de microorganismos circulantes. A baixa freqüência de parasitas no esfregaço de sangue faz com que o método não seja tão preciso, especialmente durante a fase trombocitopênica. A fim de encontrar as mórulas, uma análise cuidadosa e ampla do esfregaço sanguíneo deve ser realizada na microscopia optica. Infecções por E. canis tambem podem apresentar corpos de inclusão em algumas células do sangue, incluindo as plaquetas (Almosny 1998, D’Agnone 2006, Ramos et al. 2009), em algum estágio, e a possibilidade de visualização dos grânulos devido à ativação plaquetária não pode ser descartada. Essas inclusões podem ser erroneamente identificada como uma mórula de $A$. platys.

Corpos de inclusão em plaquetas podem estar relacionados à outras doenças (Mylonakis et al. 2003), e as plaquetas desempenham um papel importante durante os processos inflamatórios. Um achado hematológico comum durante a inflamação é a ativação plaquetária e liberação de mediadores solúveis que controlam a atividade das células sanguineas e endoteliais (Martin et al. 2005) portanto, estes corpos de inclusão citoplasmáticas são freqüentes. Essas inclusões são caracterizada pela formação de grânulos, que se concentram na região central das plaquetas como falsos núcleos, semelhantes a uma mórula (Harvey 2001). Neste estudo, a presença de corpos de inclusão em macroplaquetas observadas pela microscopia optica, foi identificada em nove amostras $(9,89 \%)$ entretanto, somente quatro foram positivas na nPCR, que identificou doze amostras $(13,19 \%)$ positivas para para A. platys . A possibilidade de infecção por um outro parasita ou grânulos devido à ativação plaquetária, não podem ser descartada, sendo assim, estudos mais detalhados sao impressindíveis.

Segundo Chang \& Pan (1996) a nested PCR é muito sensível na detecção de $A$. platys no sangue, tanto na fase aguda quanto crônica da trombocitopenia cíclica. Desta forma, o protocolo para reação de nPCR, avaliado neste trabalho, mostrou- se eficaz e específico para o diagnóstico de A.platys.
Cardozo et al. 2007 analisaram o gene $16 \mathrm{~S}$ rRNA da $A$. Platys detectado pela nPCR e descreveram a importância do seqüenciamento do DNA para desenvolvimento da especificidade e sensibilidade dos exames moleculares e para melhor caracterizar as linhagens circulantes no Brasil. A incidência de A. platys no Brasil é baixa (Macieira et al. 2005) e a caracterização molecular envolvendo a comparação de seqüências de DNA de cepas brasileiras com cepas ao redor do mundo é muito importante, porém, neste estudo não foi possível a realização do seqüenciamento das amostras positivas.

Cabe salientar que a sensibilidade da PCR na identificação de agentes erliquiais nos felinos com infecção crônica é desconhecida. Os organismos erliquiais podem ser seqüestrados no baço e não serem encontrados no sangue circulante. Se a infecção em felinos mimetiza a Rickettsiose canina, grande número de felinos com doença subclínica pode existir. Tais animais podem, dessa forma, serem identificados pela sorologia (Legendre 2002, Billeter et al. 2007). Por outro lado, os felinos podem ser capazes de debelar o parasita, porém manterem títulos de anticorpos em níveis ainda detectáveis (Billeter et al. 2007).

Apesar existirem poucos estudos sobre as alterações hematológicas, normalmente a maioria os autores citam anemias associadas às Rickettsioses em felinos (Charpentier et al. 1986; Buoro et al. 1989; Beaufils et al. 1995 e 1999, Almosny 1998, Davenport et al. 1998, Gaunt 2000, Stubbs et al. 2000, Breitschwerdt et al. 2002, Aguirre et al. 2004), no entanto neste estudo, anemia ou qualquer outra alteração na série vermelha do hemograma não foram associadas à presença de $A$. platys nos gatos pesquisados. Santiago (2010) relata que os gatos soropositivos para $E h r-$ lichia canis, também não desenvolveram anemia, mas apresentaram hematócrito aumentado, possivelmente devido à desidratação, que também foi observado por Bouloy et al. (1994) e Beaufils et al. (1999).

A trombocitopenia é um achado comum em gatos com doenças erliquiais (Almosny 1998; Almosny \& Massard 1999; Davenport 1998; Gaunt et al. 2000), porém, os resultados obtidos neste estudo corroboram com Santiago (2010) que não associou trombocitopenia com a erliquiose felina, apesar de ter encontrado casos de trombocitopenia acentuada em alguns gatos, o que também foi observado neste estudo, mas a causa dessa alteração plaquetária não foi esclarecida. Oliveira (2008) observou trombocitopenia apenas em um dos três gatos positivos para E. canis investigados por PCR.

Foi observada diferença $(\mathrm{p}<0,05)$ no leucograma dos gatos positivos e negativos para A. platys, apesar dos valores estarem dentro dos valores de referência utilizados no Laboratório de Patologia Clínica da Universidade Estadual do norte Fluminense (Lopes et al. 2007; Meyer et al. 1995). Não há relatos na literatura, de alterações no número de qualquer célula da linhagem leucocitária associados às doenças Rickettsiais em felinos. Neste estudo, observou-se que os gatos positivos apresentaram limites médios menores que os gatos negativos, ou seja, há uma tendência à neutropenia no grupo de animais positivos, como é descrito para outros agentes Rickettsiais. 
Poucos relatos existem sobre as alterações nos caracteres analisados na bioquímica sérica associados aos agentes Rickettsiais. A hiperproteinemia tem sido descrita nos gatos em vários estudos (Buoro et al. 1989, Bouloy et al. 1994, Beaufils et al. 1995, 1999, Almosny 1998, Davenport 1998, Stubbs et al. 1998, 2000, Almosny \& Massard 1999, Gaunt et al. 2000, Aguirre et al. 2004, Tarello 2005, Santiago 2010). A hiperproteinemia é originada por uma hiperglobulinemia, que por sua vez e produzida por uma hiper gamaglobulinemia, devido ao aumento da resposta humoral frente aos agentes Rickettsiais. Neste estudo não se observou alteração na proteína total sérica e suas frações (albumina e globulina) nos animais pesquisados, provavelmente pela baixa patogenicidade da A. platys em felinos domésticos diferente da E. canis relatadas pelos autores supracitados.

Santiago (2010) descreve um aumento da creatinina em gatos soropositivos, o que é esperado segundo o autor, pois esses animais podem apresentar alterações renais o que também foi relatado por Beaufils et al. (1999), Stubbs et al. $(1998,2000)$ e Aguirre et al. (2004). De acordo com Almosny \& Massard (1999), por meio de infecções experimentais por $E$. canis em felinos domésticos jovens observaram uma pequena elevação dos níveis séricos de uréia e creatinina. Os resultados obtidos nesse trabalho contradizem esses autores, onde a creatinina nos animais positivos atingiu média zero. Quanto aos níveis de uréia, não houve diferença estatística entre os animais positivos e negativos para $A$. platys, apesar de se observado casos de uremia acentuada em alguns gatos.

Em infecção experimental por E. canis em felinos domésticos jovens, Almosny \& Massard (1999), observaram um aumento da atividade sérica das transaminases e fosfatase alcalina e hipoalbuminemia. Nos gatos desse experimento, positivos e negativos para A. platys as alterações nas enzimas hepáticas não foram estatisticamente significativas. Sousa (2006) não observou alteração nos níveis de fosfatase alcalina e hipoalbuminemia tanto na fase aguda como na fase crônica da infecção por A. platys em cães parasitados e confirmados por nPCR.

0 presente estudo permite concluir que o gênero $E h r-$ lichia spp. não foi detectado, utilizando PCR convencional, enquanto a nPCR foi eficaz e específica para o diagnóstico de Anaplasma platys. Conclui também que a utilização do esfregaço sanguíneo objetivando-se encontrar corpos de inclusão mostrou-se pouco efetiva, ressalta-se inclusive que amostras positivas no esfregaço sanguíneo não demonstraram positividade para Ehrlichia spp. na PCR convencional. Já os esfregaços sanguíneos de primeira gota de sangue de ponta de orelha e a nPCR mostraram eficácia na detecção de $A$. platys. Quanto às inclusões basofílicas observadas nas plaquetas não devem ser definidas apenas como mórulas de A. platys. Ainda conclui-se que nenhuma alteração clínica, hematológica e de bioquímica sérica observada neste estudo, foi relacionada à presença de $A$. platys.

Agradecimentos.- Ao Programa de pós-graduação em Ciência Animal da Universidade Estadual do Norte Fluminense - Darcy Ribeiro (UENF) e à Coordenação de Aperfeiçoamento de Pessoal de Nível Superior (CAPES) pela concessão da Bolsa de Mestrado.

\section{REFERÊNCIAS}

Aguirre E., Tesouro M.A., Amusategui I., Rodríguez-Franco F. \& Sainz A. 2004. Assessment of feline ehrlichiosis in central Spain using serology and a polymerase chain reaction technique. Ann. N.Y. Acad. Sci. 1026:103-105.

Aguirre E., Tesouro M.A., Amusategui I., Rodríguez-Franco F. \& Sainz A. 2008. Animal biodiversity and emerging diseases: Comparison between different polymerase chain reaction methods for the diagnosis of Ehrlichia canis infection. Ann. N.Y. Acad. Sci. 1149:118-120.

Albernaz A.P., Miranda F.J.B., Melo Jr O.A., Machado J.A. \& Fajardo H.V. 2007. Erliquiose canina em Campos dos Goytacazes, Rio de Janeiro, Brasil. Ciênc. Anim. Bras. 8:799-806.

Almosny N.R.P. 1998. Ehrlichia canis (Donatien \& Lestoquard 1935): Avaliação parasitológica, hematológica e bioquímica sérica da fase adulta de cães e gatos experimentalmente infectados. Tese de Doutorado em Parasitologia, Universidade Federal Rural do Rio de Janeiro, Seropédica, RJ. 202p.

Almosny N.R.P. \& Massard C.L. 1999. Erliquiose felina: revisão. Clín. Vet. $4(23): 30-32$.

Almosny N.R.P. \& Massard C.L. 2002. Erliquiose em pequenos animais domésticos e como zoonose, p.14-56. In: Ibid. (Eds), Hemoparasitoses em Pequenos Animais Domésticos e como Zoonoses. L.F. Livros, Rio de Janeiro.

Alves L.M., Linhares G.F.C., Chaves N.S.T., Monteiro L.C. \& Linhares D.C. 2005. Avaliação de iniciadores e protocolo para o diagnóstico da Pancitopenia Tropical Canina por PCR. Ciênc. Anim. Bras. 6:49-54.

André R.A. 2008. Detecção molecular e sorológica de Ehrlichia canis e Babesia canis em felídeos silvestres brasileiros mantidos em cativeiro. Dissertação de Mestrado, Faculdade de Ciências Agrárias e Veterinárias, Unesp, Campus de Jaboticabal, São Paulo. 78p.

Beaufils J.P., Martin-Granel J. \& Jumelle P. 1995. Infection du chat par une Ehrlichia sp.: à propos de trois cas. Prat. Méd. Chir. Anim. Comp. 30:397402.

Beaufils J.P., Martin-Granel J. \& Jumelle P. 1999. Ehrlichiose féline: à propos de deux cas. Bull. Acad. Vét. de France 70:73-80.

Beaufils J.P., Breitschwerdt E.B., Hancock S.I., Hegarty B.C. \& Martin-Granel J. 2002. Ehrlichiose féline: identification genetique de l'agent chez deux chats. Pract. Med. Chirur. Anim. Comp. 37:235-238.

Belongia E.A. 2002. Epidemiology and impact of co-infections acquired from Ixodes ticks. Vector Borne Zoonotic Dis. 2(4):265-273.

Billeter S.A, Spencer J.A., Griffin B., Dykstra C.C., Blagburn B.L. 2007. Prevalence of Anaplasma phagocytophilum in domestic felines in the United States. Vet. Parasitol. 147(1/2):194-198.

Birkenheuer A.J., Levy M.G., Breitschwerdt E.B. 2003. Development and evaluation of a seminested PCR for detection and differentiation of $B a$ besia gibsoni (Asian Genotype) and B. canis DNA in canine blood samples. J. Clin. Microbiol. 41:4172-4177.

Bouloy R.P., Lappin M.R., Holland C.H., Thrall M.A., Baker D. \& O’Neil S. 1994. Clinical Ehrlichiosis in a cat. J. Am. Vet. Med. Assoc. 204(9):1475-1478.

Breitschwerdt E.B., Hegarty B.C. \& Hancock S.I. 1998. Sequential evaluation of dogs naturally infected with Ehrlichia canis, Ehrlichia chaffeensis, Ehrlichia equi, Ehrlichia ewingii, or Bartonella vinsonii. J. Clin. Microbiol. 36(9):2645-2651

Breitschwerdt E.B., Anthony C.G. \& Abrams-Ogg A.C.G. 2002. Molecular evidence supporting Ehrlichia canis-like infection in cats. J. Vet. Intern. Med. 16(6):642-649.

Buoro I.B.J., Atwel R.B., Kiptoon J.C. \& Ihiga M.A. 1989. Feline anaemia associated with Ehrlichia-like bodies in three domestic shorthaired cats. Vet. Rec. 125(17):434-436.

Cardozo G.P., Oliveira L.P., Zissou V.G., Donini I.A.N., Roberto P.G. \& Marins M. 2007. Analysis of the 16SrRNA gene of Anaplasma platys detected in dogs from Brazil. Braz. J. Microbiol. 38:478-479.

Chang W.L. \& Pan M.J. 1996. Specific amplification of Ehrlichia platys DNA from blood specimen by two-step PCR. J. Clin. Microbiol. 34(4):31423146. 
Charpentier F. \& Groulade P. 1986. Un cas d'ehrlichiose probable chen le chat. Bulletin de l'Academie Véterinaire 59:287-290.

Cohn L.A. 2003. Ehrlichiosis and related infections. Vet. Clin. North Am., Small Anim. Pract. 33(4):863-84.

D’Agnone A.S, Morais H.S.A. \& Vidotto 0. 2001. Erliquiose nos animais e no homem. Semina: Ciênc. Agrárias 22(2):191-201.

D’Agnone A.S. 2006. Caracterização molecular de espécies da família Anaplasmataceae em leucócitos e plaquetas de cães de Jaboticabal-SP e de Campo Grande-MS. Tese de Doutorado, Faculdade de Ciências Agrárias e Veterinárias, Unesp, Campus de Jaboticabal, SP. 141p.

Dahroug M.A.A. 2009. Diagnóstico molecular de parasitoses em felídeos silvestres. Dissertação de Mestrado em Ciências Veterinárias, Universidade Federal do Mato Grosso, Campo Grande, MS. 47p.

Dantas-Torres F., Figueiredo L.A. \& Brandão-Filho S.P. 2006. Rhipicefalus sanguineus (Acari: Ixodidae), the brown dog tick, parasitizing humans in Brazil. Revta Soc. Bras. Med. Trop. 39(1):64-67.

Davenport D.J. 1998. Bacterial and rickettsial diseases, p.527-545. In: Sherding R.G. (Ed.), The Cat: Diseases and clinical management. $2^{\text {nd }}$ ed. Churchill Livingstone, New York.

Dawson J.E, Abeygunawardena I., Holland C.J., Buese M.M. \& Ristic M. 1988. Susceptibility of cats to infection with Ehrlichia risticii, causative agent of equine monocytic Ehrlichiosis. Am. J. Vet. Res.12(49): 2096-2100.

Dawson J.E, Biggie K.L, Warner C.K., Cookson K., Jenkins S., Levine J.F. \& Olson J.G.1996. Polymerase chain reaction evidence of Ehrlichia chaffeensis, an etiologic agent of human ehrlichiosis, in dogs from southeast Virginia. Am. J. Vet. Res. 57:1175-1179.

De La Fuente J., Torina A., Naranjo V., Caracappa S., Di Marco V., Alongi A., Russo M., Maggio A.R. \& Kocan K.M. 2005. Infection with Anaplasma phagocytophilum in a seronegative patient in Sicily, Italy: Case report. Annals Clin. Microbiol. Antimicrob. 4:15.

Doyle C.K., Labruna M.B., Breitschwerdt E.B., Tang YW., Corstvet R.E., Hegarty B.C., Bloch K.C., Li P., Walker D.H. \& McBride J.W. 2005. Detection of medically important Ehrlichia by quantitative multicolor TaqMan Real-Time Polymerase Chain Reaction of the DSB Gene. J. Molec. Diagn. 7:504-510.

Eberhardt J.M, Neal K, Shackelford T. \& Lappin M.R. 2006. Prevalence of selected infectious disease agents in cats from Arizona. J. Feline Med. Surg. 8(3):164-168.

Ferreira R.F., Cerqueira A.M.F., Pereira A.M., Guimarães C.M., Sá A.G., Abreu F.S., Massard C.L., Almosny N.R.P. 2007. Anaplasma platys diagnosis in dogs: Comparison between morphological and molecular tests. Intern. J. Appl. Res. Vet. Med. 5(3):113-119.

Gaunt S.D. 2000. Hemolytic anemia caused by blood rickettisial agents and protozoa, p.154-162. In: Feldman B.F, Zinkl J.G. \& Jain N.C. (Eds), Schalm's Veterinary Hematology. $5^{\text {th }}$ ed. Williams and Wilkins, Philadelphia.

Georges K., Ezeokoli C.D., Newaj-Fyzul1 A., Campbell M., Mootoo N., Mutani A. \& Sparagano O.A.E. 2008. The application of PCR and reverse line blot hybridization to detect arthropod-borne hemopathogens of dogs and cats in Trinidad. Ann. N.Y. Acad. Sci. 1149:196-199.

Hancock S.I., Breitschwerdt E.B. \& Pitulle C. 2001. Differentiation of Ehrlichia platys and E. equi infections in dogs by using $16 \mathrm{~S}$ ribosomal DNA-based PCR. J. Clin. Microbiol. 39(12): 4577-4578.

Harvey J.W. 2001. Platelets, p.75-79. In: Harvey J.W. (Ed.), Atlas of Veterinary Hematology: Blood and bone marrow of domestic animals. W.B. Saunders Company Philadelphia.

Hinrichsen V.L., Whitworth U.G., Breitschwerdt E.B. \& Mather B.C.H.T.N. 2001. Assessing the association between the geographic distribution of deer ticks and seropositivity rates to various tick-transmitted disease organisms in dogs. J. Am. Vet. Med. Assoc. 218(7):1092-1097.

Inokuma H., Raoaut D. \& Brouqui P. 2000. Detection of Ehrlichia platys DNA in brown dog ticks (Rhipicephalus sangineus) in Okinawa Island, Jpn. J. Clin. Microbiol. 38(11):4219-4221.

Inokuma H., Parola P. \& Raoult D. 2001. Molecular survey of Ehrlichia infection in ticks from animals in Yamaguchi prefecture, Japan. Vet. Parasitol. 99(4):335-339.
Jain N.C. 1993. The platelets, p.105-132. In: Jain N.C. (Ed.), Essentials of Veterinary Hematology. Lea and Febiger, Philadelphia.

Johnson E.M, Ewing S.A, Barker R.W., Fox J.C., Crow D.W. \& Kocan K.M. 1998. Experimental transmission of Ehrlichia canis (Rickettsiales: Ehrlichieae) by Dermacentor variabilis (Acari: Ixodidae). Vet. Parasitol. 74(2/4):277-288.

Kaneko J.J., Harvey J.W. \& Bruss M.L. 2008. Clinical Biochemistry of Domestic Animals. $6^{\text {th }}$ ed. Academic Press, San Diego. 932p.

Kawahara M., Suto C., Rikihisa Y., Yamamoto S. \& Tsuboi Y. 1993. Characterization of ehrlichial organisms isolated from a wild mouse. J. Clin. Microbiol. 31(1) 89-96.

Kordick D., Lappin M. \& Breitschwerdt E. 1995. Feline rickettsial diseases, p.287-290. In: J. Bonagura J. (Ed.), Kirk's Current Veterinary Therapy. XII. W.B. Saunders, Philadelphia.

Lappin M.R., Breitschwerdt E.B. \& Jensen W.A. 2004. Molecular and serologic evidence of Anaplasma phagocytophilum infection in cats in North America. J. Am. Vet. Med. Assoc. 225(6):893-896.

Lappin M.R., Griffin B., Brunt J., Riley A., Burney D., Hawley J., Brewer M.M. \& Jensen W.A. 2005. Prevalence of Bartonella species, haemoplasma species, Ehrlichia species, Anaplasma phagocytophilum, and Neorickettsia risticii DNA in the blood of cats and their fleas in the United States. J. Feline Med. Surg. 8(2):1-6.

Legendre A. M. 2002. Ehrlichiosis in cats. J. Vet. Intern. Med. 16(641):614. Lima M.L.F., Soares P.T., Ramos C.A.N., Araújo F.R., Ramos R.A.N., Souza I.I.F., Faustino M.A.G. \& Alves L.C.A. 2010. Molecular detection of Anaplasma platys in a naturally-infected cat in Brazil. Braz. J. Microbiol. 41:381-385.

Lopes S.T.A, Biondo A.W, Santos A.P, Emanuelli M.P, Antoniazzi A.Q. \& Valle S.F. 2007. Manual de Patologia Clínica Veterinária. $3^{a}$ ed. Departamento de Clínica de Pequenos Animais, UFSM, Santa Maria. 107p.

Luria B.J., Levy J.K., Lappin M.R., Breitschwerdt E.B., Legendre A.M., Hernandez J.A., Gorman S.P. \& Lee I.T. 2004. Prevalence of infectious diseases in feral cats in Northern Florida. J. Feline Med. Surg. 6(5):287-96.

Machado R.Z. 2004. Ehrlichiose canina. Revta Bras. Parasitol. Vet. 13:53-57.

Macieira D.B, Messick J.B., Cerqueira A.M., Freire I.M., Linhares G.F., Almeida N.K. \& Almosny N.R. 2005. Prevalence of Ehrlichia canis infection in thrombocytopenic dogs from Rio de Janeiro, Brazil. Vet. Clin. Pathol. 34(1):44-48.

Madigan J.E., Pusterla N., Johnson E., Chae J.S., Pusterla J.B., Derock E. \& Lawler S.P. 2000. Transmission of Ehrlichia risticii, the agent of Potomac horse fever, using naturally infected aquatic insects and helminth vectors: Preliminary report. Equine Vet. J. 32(4):275-279.

Martin A. R., Brown G.K., Dunstan R.H. \& Roberts T.K. 2005. Anaplasma platys: an improved PCR for its detection in dogs. Exp. Parasitol. 109:176180.

Massung R. F. \& Slater K. 2003. Comparison of PCR assays for detection of the agent of human granulocytic ehrlichiosis, Anaplasma phagocytophilum. J. Clin. Microbiol. 41(2):717-722.

Meyer D.J., Coles E.H. \& Rich L.J. 1995. Medicina de laboratório veterinário: interpretação e diagnóstico. Roca, São Paulo. 308p.

Mylonakis M.E., Koutinas A.F., Billinis C., Leontides L.S., Kontos V., Papadopoulos O., Rallis T. \& Fytianoue A. 2003. Evaluation of cytology in the diagnosis of acute canine monocytic Ehrlichiosis (Ehrlichia canis): a comparison between five methods. Vet. Microbiol. 91(2/3):197-204.

Mylonakis M.E, Koutinas A.F., Breitschwerdt E.B., Hegarty B.C., Billinis C.D., Leontides L.S. \& Kontos V.S. 2004. Chronic canine Ehrlichiosis (Ehrlichia canis): A retrospective study of 19 natural causes. J. Am. Anim. Hosp. Assoc. 40(3):174-184.

Nicholson W.L., Muir S., Sumner J.W. \& Childs J.E. 1998. Serologic evidence of infection with Ehrlichia spp. in wild rodents (Muridae: Sigmodontinae) in the United States. J. Clin. Microbiol. 36(3):695-700.

Oliveira L.S. 2008. Investigação molecular de Ehrlichia em uma população de cães e gatos em Viçosa/ MG. Dissertação de Mestrado em Medicina Veterinária, UFV, Viçosa. 75p. 
Otranto D. \& Dantas-Torres F. 2010. Canine and feline vector-borne diseases in Italy: current situation and perspectives. Parasites and Vectors $3: 2$.

Peavy G.M., Holland C.J., Dutta S.K,, Smith G., Moore A., Rich L.J., Lappin M.R. \& Richter K. 1997. Suspected ehrlichial infection in five cats from a household. J. Am. Vet. Med. Assoc. 210(2):231-234.

Preziosi D.E. \& Cohn L.A. 2002. The increasingly complicated story of Ehrlichia. Compend. Cont. Educ. Pract. Vet. 24:277-291.

Ramos C.A.N., Ramos R.A.N., Araújo F.R., Guedes Jr D., Souza I.I.F., Ono T.M., Vieira A.S., Pimentel D.S., Rosas E.O., Faustino M.A.G. \& Alves L.C. 2009. Comparação de nested-PCR com o diagnóstico direto na detecção de Ehrlichia canis e Anaplasma platys em cães. Revta Bras. Parasitol Vet. 18(1):58-62.

SAEG 2008. Sistema de análises estatísticas e genéticas: Versão 9.0. Universidade Federal de Viçosa. Editora UFV, Viçosa. 150p.

Santiago T.A. 2010. Enfermedades vectoriales en gatos de la comunidad de Madrid: estúdio serológico, molecular y epidemiológico de la infección por Ehrlichia spp, Anaplasma spp, Neorickettsia spp, Leishmania spp y Bartonella spp. Tese de Doutorado, Universidad Complutense de Departamento de Medicina y Cirugía Animal, Facultad de Veterinaria, Madrid. 319p.

Shaw S.E., Binns S.H., Birtles R.J., Day M.J., Smithson R. \& Kenny M.J. 2005. Molecular evidence of tick-transmitted infections in dogs and cats in the United Kingdom. Vet. Rec. 157(21):645-648.

Solano-Gallego L., Hegarty B., Espada Y., Llull J. \& Breitschwerdt E.B. 2006. Serological and molecular evidence of exposure to arthropod-borne organisms in cats from northeastern Spain. Vet. Microbiol. 118(3/4):274277.

Sousa V.R.F. 2006. Avaliação clinica, morfológica, hematológica, bioquímica e biomolecular e cães naturalmente infectados por Ehrlichia canis e
Anaplasma platys. Tese de Doutorado, Universidade Federal Rural do Rio de Janeiro, Seropédica, RJ. 58p.

Statplus 2009. Professional: Programa Estatístico disponível em <http:// www.analystsoft.com/br/products/statplus> Stubbs C. J. \& Holland C.J. 2000. Feline Ehrlichiosis. Compend. Cont. Educ. Pract. Vet. 22: 307-317.

Tabar M.D., Altet L., Francino O., Sanchez A. \& Ferrer L. 2008 Vector-borne infections in cats: Molecular study in Barcelona area (Spain). Vet. Parasitol. 151(2/4):332-336.

Tamí I.C. \& Tamí-Maury I.M. 2004. Identificación morfológica de Ehrlichia sp. en las plaquetas de pacientes con infección por virus de la inmunodeficiencia humana, en Venezuela. Revta Panam. Salud Publica 16(5):345-349.

Tarello W. 2005. Microscopic and clinical evidence for Anaplasma (Ehrlichia) phagocytophilum infection in Italian cats. Vet. Rec. 156(24)772774.

Vinasco J., Li O., Alvarado A., Diaz D., Hoyos L., Tabachi L., Sirigireddy K., Ferguson C. \& Moro M.H. 2007. Molecular evidence of a new strain of Ehrlichia canis from South America. J. Clin. Microbiol. 45:27162719.

Vita S., Santori D., Aguzzi I., Petrotta E. \& Luciani A. 2005. Feline leishmaniasis and Ehrlichiosis: serological investigation in Abruzzo region. Vet. Res. Commun. 29(2):319-321.

Wen B., Rikihisa Y., Mott J.M., Greene R., Kim H.Y., Zhi N., Couto G.C., Unver A. \& Bartsch R. 1997. Comparison of nested PCR with immunofluorescentantibody assay for detection of Ehrlichia canis infection in dogs treated with doxycicline. J. Clin. Microbiol. 35(7):1852-1855.

Yin-Chiachun, Liu-Hungjen, Lin-Suenchuain, Liao-Minghuei \& Wu-Yeonghuey 2003. Identification of Ehrlichia canis in cats by nested polimerase chain reaction and nucleotide sequence analysis. Taiwam Vet. Journal, Taipei, 29(2):122-128. 